\title{
ОСОБЛИВОСТІ ВИКОРИСТАННЯ БЕСІДИ, ЯК ФОРМИ АКТИВНОГО НАВЧАННЯ, ПІД ЧАС ВИХОВНОГО ТА НАВЧАЛЬНОГО ПРОЦЕСУ НА КАФЕДРІ НЕВРОЛОГІЇ ОДЕСЬКОГО НАЦІОНАЛЬНОГО МЕДИЧНОГО УНІВЕРСИТЕТУ
}

Т. М. Муратова, В. В. Добровольський

Одеський начіональний медичний університет

\author{
FEATURES OF USE CONVERSATION AS A FORM OF ACTIVE \\ LEARNING, DURING EDUCATIONAL AND TRAINING PROCESS \\ AT THE NEUROLOGY DEPARTMENT OF ODESA NATIONAL \\ MEDICAL UNIVERSITY
}

\author{
T. M. Muratova, V. V. Dobrovolskyi \\ Odesa National Medical University
}

\begin{abstract}
У статті представлений аналіз методичних підходів, зокрема бесіди, як форми активного навчання, під час виховного та навчального процесу студентів на кафедрі неврології Одеського національного медичного університету.

The article presents an analysis of methods, including conversation, as a form of active learning, during educational and training process of students at the Department of Neurology of Odesa National Medical University.
\end{abstract}

Вступ. Викладачі кафедри під час спілкування 3 студентами використовують індивідуальну бесіду як дійову форму взаємодії.

Володіння такою формою спілкування дуже важливо для педагога завдяки двом чинникам.

По-перше, така необхідність пов'язана зі студентами, у яких виникають труднощі під час засвоювання матеріалу, як на лекції, так і під час самостійної роботи.

По-друге, викладач повинен навчити студента спілкуватися з пацієнтом, про такі підходи говорить у своїй статті академік В. М. Запорожан, який підкреслює, що хворобу можливо подолати лише за умови активного спілкування лікаря і пацієнта, а ефективне навчання студента можливе безпосередньо біля ліжка хворого: "Ще Конфуцій казав: "Я почув - і забув, я побачив і запам'ятав, я зробив - i зрозумів". Ця формула якнайкраще ілюструє необхідність поліпшення практичної складової в системі підготовки лікаря [1].

На кафедрі неврології щорічно навчаються близько 30 груп студентів (медичні факультети (№ 1, 2, 3, 4) 14 груп, міжнародний факультет - 10 груп, стоматологічний факультет - 7 груп), серед них 60 \% вітчиз-

(c) Т. М. Муратова, В. В. Добровольський няних та 30 \% іноземних), які залежно від менталітету, підготовки, знання мови потребують максимально індивідуального підходу викладача. Під час перескладання бесіда дає можливість не тільки виявити знання слухача, а й здійснити виховний вплив на студента.

Іноземні студенти, особливо з арабських країн, Індії, Китаю в силу менталітету та непорозумінь частіше вважають необхідним індивідуально поспілкуватися 3 викладачем.

Основна частина. Які якості, на наш погляд, необхідні педагогу для успішного проведення бесіди, яка використовується для спілкування зі студентами і має навчальну спрямованість, особливо в умовах співробітництва, коли студенти працюють самостійно? Як правило, такі бесіди не викликають труднощів у педагога, навпаки, приносять задоволення, бо мають творчий характер.

По-перше, для проведення бесід виховного характеру, необхідно мати високий рівень культури спілкування, знання загальної і соціальної психології. Особливість таких бесід у тому, що це взаємодія двох особистостей, які повинні цінувати гідність одне одного.

Студенти відчувають до себе увагу та повагу, стають зацікавленими партнерами у спілкуванні. До ро- 
зуміння цього нас підводять праці видатних психологів та педагогів, таких, як: В. Сухомлинський, К. Роджерс та ін. [2].

По-друге, педагог може проводити індивідуальну бесіду зі студентом у різних умовах: в аудиторії, під час перерви, під час неформальної бесіди, перездачі та відпрацювання пропущених тем [3].

На кафедрі створені умови, які сприяють невимушеності розмови. Зроблено все, щоб не було формалізму, нотацій менторства, залякування. Відомо, що коли у студента з'являється почуття страху, то він не змінюється на краще і при першій нагоді зробить те саме. А стосовно педагога у нього сформується негативна установка. 3 метою покращення та удосконалення педагогічних аспектів навчання і виховання в нашому університеті щорічно проводяться семінари з актуальних тем педагогіки для того, щоб педагог у тактовній формі міг висловити студентові свої зауваження, презентації, вимоги, які б допомагали йому краще аналізувати та засвоювати предмет.

Перш за все починаючи бесіду зі студентом, бажано почати розмову про його інтереси, успіхи, гарні вчинки. Такий початок сприяє встановленню контакту, позитивності атмосфери в розмові. На довіру молодь найчастіше відповідає довірою.

Далі в розмові бажано поступово перейти до обговорювання конкретної теми, яка викликає занепокоєність, а то й труднощі в аналізуванні [4].

Головним напрямком, на наш погляд, є особистий приклад керівництва університету і кафедри, які знаходять час для співбесід 3 професорсько-викладацьким складом, створюючи позитивний мікроклімат у колективі університету. В системі виховного впливу на навчальний процес сплановані семінари з психології та круглі столи (обговорювання питань) 3 педагогами, в першу чергу в останні роки приділяється увага індивідуальній виховній роботі з викладачами і студентами, де на перший план ставиться вміння проводити індивідуальну бесіду. Викладачам рекомендовано індивідуально вести співбесіди, або використовувати елементи співбесіди:

- під час прийому іспитів;

- під час чергування по гуртожитку, що дає найбільший ефект;

- в період відпрацювання пропущених тем;

- дуже важливо використати особистий приклад викладача при співбесіді з хворим біля його ліжка.

При цьому можливо не навішувати ярликів, а говорити не про особистисть в цілому, а про конкретний підхід до навчання.
Пропозиції, думки педагога-викладача повині бути конкретними і конструктивними.

Бажано не нав' язувати співрозмовнику своїх порад, а оцінку його вчинкам давати лише в крайніх випадках. Слід вести розмову так, щоб співбесідник сам або зробив потрібний висновок, або ж попросив педагога-викладача порадити йому, як надалі діяти в подібних випадках при лікуванні пацієнта [3].

I, нарешті, важливо закінчити бесіду на оптимістичній ноті, висловити свою віру в студента, його особистість, особливо це важливо в бесіді лікаря 3 пацієнтом, коли можливо разом із тим намітити систему перспективних дій, позитивних змін. Добре і надалі, спілкуючись $з$ пацієнтом, допомагаючи йому, запобігти депресії та націлити на одужання.

Які ж напрямки роботи по використанню індивідуальних бесід:

- в силу вікового цензу в університеті навчаються студенти після школи, яких більше 50 \%, тому є велика необхідність близького спілкування з батьками студентів, після бесіди з якими викладач має змогу використовувати їх у спілкуванні зі студентами;

- що стосується іноземних студентів, то позитивний ефект дають індивідуальні бесіди з керівниками національних груп, це дає можливість вивчення звичаїв, менталітету, і використання цих особливостей у роботі.

Викладачам рекомендовано після індивідуальних бесід аналізувати, робити висновки і використовувати це у своїй педагогічній діяльності.

Висновки. Таким чином, можна сказати, що бесіди різних видів $\epsilon$ ефективною формою для встановлення взаємопорозуміння між викладачем медичного університету і студентами.

В університеті та на кафедрі до цього питання ставляться значно ширше.

В першу чергу, це особливий приклад керівництва університету та кафедри, коли незважаючи на зайнятість, метод бесіди з підлеглими дозволяє створити робочу атмосферу в колективі.

По друге, стоїть завдання навчити лікаря мистецтва вести бесіду з пацієнтом.

Це важливо в період реформування медицини, економічної кризи, коли лікарям загальної практики і сімейної медицини необхідно протягом нагляду за хворим знаходити підхід до людей різних верств населення, різного віку.

I по-третє, підготовка викладачів кафедри неврології, які безпосередньо спілкуються зі студентами і виконують два завдання: навчити студентів на осо- 
бистому прикладі індивідуальної бесіди та роблять все можливе, щоб успішне використання індивідуальної бесіди сприяло підвищенню якості навчального,

\section{Списоклітератури}

1. Запорожан В. М. Без инновационных методов обучения подготовить современного врача невозможно / В. М. Запорожан // Медична газета "Ваше здоров'я" 2014. - 4 квіт. - http://www.vz.kiev.ua/ru/valerij-zaporozhanbez-innovacijnix-metodiv-navchannya-pidgotuvatisuchasnogo-likarya-nemozhlivo/

2. Мицич П. Как проводить деловые беседы / П. Мицич ; пер. с сербско-хорват.-М., 1987.-С. 194. виховного процесу на кафедрі і в університеті взагалі.

3. Зельдович Б. З. Деловое общение : учебное пособие / Б. 3. Зельдович. - М. : Издательство Альфа-Пресс, 2007.$456 \mathrm{c}$.

4. Столяренко Л. Д. Психология делового общения и управления. Учебник / Л. Д. Столяренко. - Ростов н/Д : Феникс, 2005. -416 с.

Отримано 22.12.14 